\title{
Detection of the pediocin gene pedA in strains from human faeces by real-time PCR and characterization of Pediococcus acidilactici UVA I
}

\author{
Sophie Mathys ${ }^{\dagger}$, Ueli von $\mathrm{Ah}^{\dagger}$, Christophe Lacroix, Ernö Staub, \\ Raffaella Mini, Tania Cereghetti and Leo Meile*
}

Address: Laboratory of Food Biotechnology, Institute of Food Science and Nutrition, Swiss Federal Institute of Technology (ETH), Zurich, Switzerland

Email: Sophie Mathys - sophie.mathys@ilw.agrl.ethz.ch; Ueli von Ah - ueli.vonah@ilw.agrl.ethz.ch;

Christophe Lacroix - christophe.lacroix@ilw.agrl.ethz.ch; Ernö Staub - estaub@student.ethz.ch; Raffaella Mini - minir@student.ethz.ch; Tania Cereghetti - taniac@student.ethz.ch; Leo Meile* - leo.meile@ilw.agrl.ethz.ch

* Corresponding author †Equal contributors

Published: 12 September 2007

BMC Biotechnology 2007, 7:55 doi:10.1 I86/1472-6750-7-55
Received: 9 February 2007

Accepted: 12 September 2007

This article is available from: http://www.biomedcentral.com/l472-6750/7/55

(c) 2007 Mathys et al; licensee BioMed Central Ltd.

This is an Open Access article distributed under the terms of the Creative Commons Attribution License (http://creativecommons.org/licenses/by/2.0), which permits unrestricted use, distribution, and reproduction in any medium, provided the original work is properly cited.

\begin{abstract}
Background: Bacteriocin-producing lactic acid bacteria are commonly used as natural protective cultures. Among them, strains of the genus Pediococcus are particularly interesting for their ability to produce pediocin, a broad spectrum antimicrobial peptide with a strong antagonistic activity against the food-borne pathogen Listeria monocytogenes. Furthermore, there is increasing interest in isolating new bacteriocin-producing strains of human intestinal origin that could be developed for probiotic effects and inhibition of pathogenic bacteria in the gut. In this work, we typed a new strain, co-isolated from baby faeces together with a Bifidobacterium thermophilum strain, and characterized its proteinaceous compound with strong antilisterial activity.

Results: The newly isolated strain UVAI was identified as a Pediococcus acidilactici by carbohydrate fermentation profile, growth at $50^{\circ} \mathrm{C}$ and $16 \mathrm{~S}$ rDNA sequencing. The partially purified bacteriocin was heat resistant up to $100^{\circ} \mathrm{C}$, active over a wide range of $\mathrm{pH}(2$ to 9$)$ and susceptible to proteolytic enzymes. The molecular weight, estimated by SDS-PAGE, was similar to that of pediocin AcH/PA-I ( $4.5 \mathrm{kDa})$. P. acidilactici UVAI harboured a $9.5-\mathrm{kb}$ plasmid that could be cured easily, which resulted in the loss of the antimicrobial activity. Southern hybridization using the DIGlabelled pedA-probe established that the bacteriocin gene was plasmid-borne as for all pediocin described so far. Nucleotide sequence of the whole operon $(3.5 \mathrm{~kb})$ showed almost $100 \%$ similarity to the pediocin AcH/PA-I operon. The mRNA transcript for pedA could be detected in P. acidilactici UVAI but not in the cured derivative, confirming the expression of the pedA-gene in UVAI. Using a new real-time PCR assay, eleven out of seventeen human faecal samples tested were found to contain pedA-DNA.
\end{abstract}

Conclusion: We identified and characterised the first pediocin produced by a human intestinal Pediococcus acidilactici isolate and successfully developed a new real-time PCR assay to show the large distribution of pedA-containing strains in baby faecal samples. 


\section{Background}

The lactic acid bacteria are an inhomogeneous group which includes among others the genera Pediococcus, Enterococcus, Lactococcus, Lactobacillus and Streptococcus. Among the Pediococcus group, P. acidilactici and P. pentosaceus are widely used for fermentation of food products like vegetable and meat products. By production of organic acids, resulting in $\mathrm{pH}$ decrease, they contribute to control the microbial succession during fermentation. They also act as protective cultures preventing the growth of food-borne pathogens such as Listeria monocytogenes or Staphylococcus aureus [1] and by doing this, they extend storage life and enhance safety of food products $[2,3]$. Beside production of classical antimicrobial compounds such as organic acids or hydrogen peroxide, the protective effect also results from the production of bacteriocins [4]. Bacteriocins are ribosomally synthesized, small, heat-stable antimicrobial peptides produced by bacteria. Pediocin AcH/PA-1 is the most studied class IIa bacteriocin (non modified, nonlantibiotic peptides) and has potential for use as food preservative, due to its strong antilisterial activity [5]. Since amino-acid sequence determination of the pediocin AcH/PA-1 in 1992 [6,7], several pediocinproducing $P$. acidilactici and $P$. pentosaceus strains have been screened from a large variety of plants and fruits [8], but also from the gastrointestinal tract of poultry, ducks and other animals [9-11]. Millette et al. [12] recently isolated a strain of Pediococcus acidilactici from human faeces which produces an unidentified antimicrobial proteinaceous compound. To our knowledge, no pediocin-producing Pediococcus has been isolated so far from human faeces and it is therefore unknown to which extent these strains are widespread in the human intestinal microbiota and contribute to the microbial balance of the complex gut ecosystem.

Real-time PCR is a very sensitive and rapid molecular method for the detection of specific genes in complex samples. It is particularly suitable for measuring non cultivable bacteria, because detection is independent of growth conditions of the target organism [13]. It has for example recently been used successfully on faecal samples to assess the survival of Lactococcus lactis subsp. cremoris FC after transit through the gastrointestinal tract [14] or to detect the presence of noroviruses in clinical stool samples [15].

In this work, we report the identification of a new bacteriocin-producing strain of Pediococcus acidilactici (UVA1), which was co-isolated from baby faeces with the bacteriocinogenic strain Bifidobacterium thermophilum RBL67 [16]. The biochemical and genetic characterization of the antimicrobial compound was performed. The distribution of pedA-containing strains in human faeces was also investi- gated using a newly designed real-time PCR assay targeting the pediocin structural gene.

\section{Methods \\ Bacterial strains, and growth conditions and plasmid- curing}

Lactobacillus paracasei subsp. paracasei DSM5622 ${ }^{\mathrm{T}}$, Pediococcus acidilactici DSM $20284^{\mathrm{T}}$ and Pediococcus pentosaceus DSM 20336 ${ }^{\mathrm{T}}$ (obtained from DSMZ GmbH, Braunschweig, Germany) were used as reference strains for analysis of the carbohydrate fermentation profile. Listeria ivanovii HPB28 (obtained from the Health Protection Branch, Health and Welfare, Ottawa, Canada) was used as indicator strain for the detection of pediocin activity [17]. P. acidilactici UL5 (own culture collection) was used as pediocin producer control [17]. Pediococcus acidilactici UVA1 was previously isolated from human baby faeces as a stable consortium with the Bifidobacterium strain RBL67 [16], which was recently identified as Bifidobacterium thermophilum. Strain UVA1 was purified by subsequent selective plating and analysis of single colonies by genusspecific probes (von Ah, unpublished). A non-bacteriocin producing derivative of $P$. acidilactici UVA1, named bac-, was obtained after curing by novobiocin treatment (Sigma-Aldrich Chemie GmbH, Buchs, Switzerland, 0.1 $\mu \mathrm{g} \mathrm{ml}^{-1}$ ) as already described [18]. Sixty colonies were screened by the overlay method for absence of antimicrobial activity against $L$. ivanovii HPB28 and four mutants producing no inhibition halo were detected. One of them was purified on MRSC agar, consisting of MRS ([19] Biolife, Milan, Italy) supplemented with $0.05 \%$ Lcysteine hydrochloride and $1.5 \%$ agar, and propagated in MRSC broth. The cell-free supernatant was checked for the absence of antilisterial activity and absence of the pedAgene was confirmed by PCR.

All lactic acid bacteria were routinely grown overnight in MRSC medium, with incubation at $37^{\circ} \mathrm{C}$ in anaerobic jars with an atmosphere generation system (Oxoid AnaeroGen TM, Basel, Switzerland). L. ivanovii HPB28 was propagated in TSY medium consisting of tryptic soy broth (Oxoid) containing $0.6 \%(\mathrm{w} / \mathrm{v})$ yeast extract (Merck, Darmstadt, Germany) overnight at $30^{\circ} \mathrm{C}$. For agar plates and soft-agar, the media were supplemented with $1.5 \%$ and $0.75 \%(\mathrm{w} / \mathrm{v})$ agar, respectively. Bacterial stocks were stored at $-80^{\circ} \mathrm{C}$ in appropriate media supplemented with $33 \%(\mathrm{v} / \mathrm{v})$ glycerol and subcultured three times at one day intervals on fresh agar plates before use. Cultures were routinely checked under a light microscope for contamination.

\section{Carbohydrate fermentation profile}

The carbohydrate fermentation profile of strain UVA1 was determined using API 50 fermentation strips (BioMérieux, Marcy l'Etoile, France). A 2-ml volume of an overnight 
culture $(16 \mathrm{~h})$ was centrifuged at $14^{\prime} 000 \times \mathrm{g}$ for $5 \mathrm{~min}$ at $4^{\circ} \mathrm{C}$. The pellet was washed once and resuspended in $1 \mathrm{ml}$ of sterile, double distilled water. The suspension was then added to $5 \mathrm{ml}$ of CHL 50 medium (prepared according to the manufacturer's instructions). Each tube of the API CHL50 strips was then inoculated with $100 \mu$ l of the bacterial suspension in CHL50 medium and sealed with sterile paraffin. The strips were incubated at $37^{\circ} \mathrm{C}$ under anaerobic conditions, the results were visually assessed after 24, 48 and $72 \mathrm{~h}$ and analysed with the APILAB+ software version 3.3.3 according to the manufacturer's instructions. P. acidilactici UL5, P. acidilactici DSM20284 ${ }^{\mathrm{T}}$, $P$. pentosaceus DSM20336 ${ }^{\mathrm{T}}$, and L. paracasei subsp. paracasei DSM5622 ${ }^{\mathrm{T}}$ were used as reference strains. All tests were repeated three times.

\section{Determination of growth at $50^{\circ} \mathrm{C}$}

Strain UVA1 was incubated at $50^{\circ} \mathrm{C}$ in $20 \mathrm{ml} \mathrm{MRSC}$ medium inoculated with $1 \%$ of an overnight culture. $P$. acidilactici UL5 and DSM20284 ${ }^{\mathrm{T}}$ and $P$. pentosaceus DSM20336 ${ }^{\mathrm{T}}$ were used as controls. The optical density at $600 \mathrm{~nm}$ was measured with an Uvikon 810P photometer (Kontron Instruments, Rotkreuz, Switzerland) after 4, 24 and $96 \mathrm{~h}$. The ability to grow at $50^{\circ} \mathrm{C}$ was positive if $\mathrm{OD}_{600}$ exceeded 0.4 after $96 \mathrm{~h}$. $\mathrm{OD}_{600}$ of 0.4 was set as the limit of growth and corresponded to twice the value of the OD of freshly inoculated medium. All tests were performed twice.

\section{Inhibition assay}

Antibacterial activity was assessed by the agar-well diffusion method. Briefly, $25 \mathrm{ml}$ of soft-agar (heated at $45^{\circ} \mathrm{C}$ ) was inoculated with $0.1 \%$ of an overnight culture of the indicator strain L. ivanovii HBP28, poured into a Petri dish and allowed to set for $30 \mathrm{~min}$ at room temperature. Holes (diameter of $7 \mathrm{~mm}$ ) were then punched in the agar and filled with $80 \mu \mathrm{l}$ of sample. The plates were incubated at $4^{\circ} \mathrm{C}$ for $30 \mathrm{~min}$ to allow bacteriocin diffusion and overnight at $30^{\circ} \mathrm{C}$ for growth of the indicator strain. The diameter of the inhibition zone was measured.

\section{Effect of temperature, $p H$, enzymes and other agents on bacteriocin activity}

Cell-free supernatant (CFS) was obtained after centrifugation at $13^{\prime} 000 \mathrm{~g}$ for $10 \mathrm{~min}$ at $4^{\circ} \mathrm{C}$ of a 16 -h culture in MRSC at $\mathrm{pH} 6$ and $37^{\circ} \mathrm{C}$. The supernatant was heated 5 min at $95^{\circ} \mathrm{C}$. The effect of temperature on the antibacterial activity was tested after heating at $121^{\circ} \mathrm{C}$ for $15 \mathrm{~min}$ in an autoclave and at $100^{\circ} \mathrm{C}$ for 60 and 40 min using a water-bath. The effect of $\mathrm{pH}$ was tested by adjusting the $\mathrm{pH}$ of the CFS to values in a range from 2 to 11 using either $1 \mathrm{M} \mathrm{HCl}$ or $1 \mathrm{M} \mathrm{NaOH}$. Residual activity was measured by the agar-well diffusion method, after one day, one week and one month storage at $4^{\circ} \mathrm{C}$. To test the sensitivity to proteases and other agents, the CFS was incubated for
$2 \mathrm{~h}$ at $37^{\circ} \mathrm{C}$ in the presence of $1 \mathrm{mg} \mathrm{ml}^{-1}$ chymotrypsin, pepsin, protease, proteinase $\mathrm{K}$, trypsin or lysozyme or $1 \%$ SDS, urea, catalase, RNAse A, Tween 20, Tween 80, Triton$\mathrm{X}$ or 2,5 or $10 \mathrm{mM}$ EDTA. For enzyme denaturation, the samples were finally heated at $95^{\circ} \mathrm{C}$ for $5 \mathrm{~min}$ and residual activity was measured by the agar-well diffusion method. All enzymes and other chemicals were purchased from Sigma-Aldrich Chemie GmbH (Buchs, Switzerland), except proteinase $\mathrm{K}$ and trypsin, which were obtained from Applichem (Darmstadt, Germany). Residual activity was defined as the ratio of the diameter of the halo produced by the treated sample compared to the untreated control and expressed in percentage. All assays were performed twice

\section{Molecular weight determination}

The bacteriocin produced by $P$. acidilactici UVA1 was partially purified by injecting $300 \mathrm{ml}$ CFS at a rate of $1 \mathrm{ml}$ $\mathrm{min}^{-1}$ in a $60-\mathrm{ml}$ SP Sepharose column connected to a FPLC chromatography system (Ätka Purifier 10, Amersham, Otelfingen, Switzerland). The column was first equilibrated with 10 column volumes of $5 \mathrm{mM}$ ammonium acetate buffer ( $\mathrm{pH} 5.0), 5-\mathrm{ml}$ fractions were collected in a fraction collector (Frac-950, Amersham) and the bacteriocin-like activity was eluted with $0.45 \mathrm{M} \mathrm{NaCl}$ in the same buffer. The CFS and active fractions after FPLC were 10-fold concentrated by ultrafiltration (cutoff of 3 $\mathrm{kDa}$ ) and $15 \mu \mathrm{l}$ of the samples were loaded on two parallel SDS gels, along with $10 \mu \mathrm{l}$ of Polypeptide SDS-PAGE molecular weight standard (BioRad Laboratories AG, Reinach, Switzerland). The gels were prepared according to Schägger and Jagow [20] and consisted of a $10 \%$ acrylamide-bisacrylamide stacking gel and a $16.5 \%$ separating gel. Separation was done with constant voltage (100 V) for 2 h 30 using a vertical slab gel apparatus (BioRad Laboratories). One of the gels was stained with Coomassie brilliant blue R250 (LK Bromma, Villeneuve-laGarenne, France) and the other was used for activity detection: the gel was first soaked for $2 \mathrm{~h}$ in fixation solution (20\% isopropanol, $10 \%$ acetic acid) and rinsed overnight in HPLC-grade water before being overlaid with $25 \mathrm{ml}$ soft TSY agar inoculated with $0.1 \%$ of an overnight culture of L. ivanovii HBP28. The molecular weight was estimated by comparison of the mobility of the inhibition zone to that of the molecular weight marker run simultaneously. The whole procedure was repeated twice.

\section{DNA sequencing and PCR conditions}

Sequencing of DNA was performed by Microsynth (Balgach, Switzerland) and similarity searches were conducted with the BLAST program from NCBI (version 2.2.15). Primers and probe used in this study are listed in Table 1. They were designed with the program Primer3 [21] and synthesised by Microsynth. The PCR reactions were set up in a total volume of $50 \mu \mathrm{l}$ containing $2.5 \mathrm{U}$ EuroTaq-DNA- 
Polymerase (Digitana, Horgen, Switzerland), $1.5 \mathrm{mM}$ magnesium chloride (Digitana), $0.2 \mathrm{mM}$ dNTP's (GE Healthcare), $0.5 \mu \mathrm{M}$ of each primer and either $2 \mu \mathrm{l}$ of DNA or $40 \mu \mathrm{l}$ of cell suspension (prepared by resuspending a single colony in $210 \mu \mathrm{l}$ of sterile, double distilled water). The $16 \mathrm{~S}$ rDNA of $P$. acidilactici UVA1 and UL5 were amplified using a slightly modified protocol from Schürch [22]. The annealing temperature for the bak $11 \mathrm{w} / \mathrm{bak} 4$ primers was increased to $62^{\circ} \mathrm{C}$. The $16 \mathrm{~s}$ rDNA sequences of UVA1 and UL5 are deposited at GenBank under accession numbers [GenBank: EF059986] and [GenBank: EF059987], respectively. For the amplification and sequencing of the first 711 bp of the pediocin PA-1 operon, primers P1 and P2 and conditions described by Rodriguez et al. [23] were used. The second part of the operon (2864 bp) was amplified with primers pedopF and pedopR, designed on the basis of the reported sequence for PSRQ11 [24]. Amplification conditions were as follow: $2 \mathrm{~min}$ at $95^{\circ} \mathrm{C}, 30$ cycles of $1 \mathrm{~min}$ at $94^{\circ} \mathrm{C}, 35 \mathrm{~s}$ at $45^{\circ} \mathrm{C}$ and $3 \mathrm{~min}$ at $72^{\circ} \mathrm{C}$ and final elongation step $7 \mathrm{~min}$ at $72^{\circ} \mathrm{C}$. Oligonucleotides pedopF and pedopR as well as pedseq $A, B, C$ and $D$, designed every $500 \mathrm{bp}$ along the PCR product, were used as sequencing primers. Additionally, a 1009-bp sequence directly upstream and a 1417-bp sequence directly downstream of the operon were amplified and sequenced with primer pairs pedseq $\mathrm{L}$ and $\mathrm{H}$ and pedseq $\mathrm{M}$ and $\mathrm{N}$, respectively. Amplification conditions were: $3 \mathrm{~min}$ at $95^{\circ} \mathrm{C}, 30$ cycles of $1 \mathrm{~min}$ at $95^{\circ} \mathrm{C}, 35 \mathrm{~s}$ at $55^{\circ} \mathrm{C}$ and $2 \mathrm{~min}$ at $72^{\circ} \mathrm{C}$ and final elongation step $7 \mathrm{~min}$ at $72^{\circ} \mathrm{C}$.

\section{Plasmid isolation and Southern blotting}

Extrachromosomal DNA elements were extracted from $P$. acidilactici UVA1, UL5 and the bac- mutant using a modified method after Anderson and McKay for small scale plasmid isolation [25]. Shortly, for cell lysis, $9.5 \mu \mathrm{l}$ mutanolysin (1500 U ml-1 Sigma-Aldrich Chemie GmbH) was added to the lysis solution (solution $\mathrm{B}$ ) and plasmid DNA was resuspended in $1 \times$ TE buffer. Finally, the RNA was digested with $10 \mu \mathrm{g}$ RNase A (Sigma-Aldrich Chemie $\mathrm{GmbH})$. The DNA was visualized after electrophoresis on a $0.65 \%$ agarose gel in $1 \times$ TBE at $100 \mathrm{~V}$ for $1 \mathrm{~h} 30$. The supercoiled DNA ladder (Promega, Madison WI, USA) was used as size standard. DIG-labelling of the pedA-probe (P1-P2 PCR product on $P$. acidilactici UVA1), blotting on nylon membrane, hybridisation (at $42^{\circ} \mathrm{C}$ ) and chemiluminescent detection were conducted with the DIG-High Prime DNA Labeling and Detection Starter Kit II (Roche Diagnostics, Rotkreuz, Switzerland) according to supplier's instructions. Plasmid preparation, blotting and hybridization were performed twice.

\section{RNA isolation and reverse transcription}

The RNA was isolated during the exponential growthphase of $P$. acidilactici UVA1, bac-, UL5 and DSM 20284 ${ }^{\mathrm{T}}$, and $P$. pentosaceus DSM $20336^{\mathrm{T}}$ using the RNeasy Mini kit
(Qiagen, Basel, Switzerland). The protocol was slightly modified by addition of $20 \mathrm{U}$ mutanolysin in the lysis solution. The samples were finally treated with RNase-free DNAse I (Invitrogen, Basel, Switzerland) for $30 \mathrm{~min}$ at $37^{\circ} \mathrm{C}$. First strand cDNA synthesis was performed with the Omniscript reverse transcription kit (Qiagen) and $5 \mu \mathrm{l}$ of the product were used for PCR amplification of a $100 \mathrm{bp}$ fragment with primers pedA2RTF and pedA2RTR. PCR products were separated on a $2 \%$ agarose gel in $1 \times$ TAE buffer by electrophoresis at $90 \mathrm{~V}$ for $2 \mathrm{~h} 30$. The low molecular weight DNA ladder and Tridye 100 bp DNAladder (New England BioLabs, Ipswich, MA, USA) were used as size standards.

\section{Preparation of DNA from faecal samples}

Twenty-one human faecal samples were collected in collaboration with the Department of Gastroenterology (Hospital for Sick Children, Zurich, Switzerland). Thirteen faecal samples were collected from children donors aged one month to 3 years and 4 from adults. Faecal samples were collected within $1 \mathrm{~h}$ after defecation, placed in anaerobic jars and rapidly transported to our laboratory. They were immediately frozen at $-20^{\circ} \mathrm{C}$ upon arrival, i.e. no more than $3 \mathrm{~h}$ after defecation. Total DNA was isolated from $200 \mathrm{mg}$ of each sample using the QIAamp DNA Stool Mini kit (Qiagen) according to the manufacturer's instructions. Before DNA extraction, one faecal sample was autoclaved twice $\left(121^{\circ} \mathrm{C}, 15 \mathrm{~min}\right)$ to obtain a sample free of DNA. Ten aliquots of this sample were spiked with a 10-fold serial dilution of $P$. acidilactici UVA1 (overnight culture in MRSC) at concentrations ranging from $10^{9}$ to $10^{1}$ bacteria cells per $\mathrm{g}$ faeces. The extracted DNA was stored at $-20^{\circ} \mathrm{C}$.

\section{Real-time PCR}

Primers and TaqMan probe listed in Table 1 were designed based on the pedA sequence with the software PrimerExpress 1.5 (Applied Biosystems, Rotkreuz, Switzerland) and synthesized by Microsynth. The TaqMan probe was labeled with 5'-FAM as a fluorescent reporter dye and 3'-TAMRA as a quencher. Their specificity was tested using the BLAST program from NCBI. Reactions were set in a total volume of $25 \mu \mathrm{l}$, containing $2.5 \mu \mathrm{l}$ of faecal DNA extract, $12.5 \mu \mathrm{l}$ of qPCR MasterMix from Eurogentec (Seraing, Belgium), $0.3 \mu \mathrm{M}$ of each primer and 0.1 $\mu \mathrm{M}$ of the TaqMan probe. Reactions were run on an ABI PRISM 7700 Sequence Detector (Applied Biosystems, Rotkreuz, Switzerland). The amplification conditions were $2 \mathrm{~min}$ at $50^{\circ} \mathrm{C}, 10 \mathrm{~min}$ denaturation at $95^{\circ} \mathrm{C}$, followed by 45 cycles of $15 \mathrm{sec}$ at $95^{\circ} \mathrm{C}$ and $1 \mathrm{~min}$ at $60^{\circ} \mathrm{C}$. The cycle threshold ( $\mathrm{Ct}$ ), corresponding to the number of cycle after which the target-DNA concentration increase become exponential, was monitored. Results were analysed using the SDS 2.1 Software (Applied Biosystems). 
Table I: Primers and probe used in this study

\begin{tabular}{|c|c|c|c|c|}
\hline Primer/probe & Target/specificity & Sequence (5'-3') & Product size (bp) & Reference \\
\hline BakIIw & I6S rDNA & AGT TTG ATC MTG GCT CAG & & [35] \\
\hline Bak4 & & AGG AGG TGA TCC ARC CGC A & & [36] \\
\hline $\mathrm{PI}$ & pedA-pedB & AAA ATA TCT AAC TAA TAC TTG & & \\
\hline P2 & & TAA AAA GAT ATT TGA CCA AAA & 711 & [23] \\
\hline pedopF & pedB-pedD & GGG CGA GTT TAA CAT GCT AGA & & \\
\hline pedopR & & TGA TTA TGA ATT AAC CGT GCA & 2862 & This study \\
\hline pedseqA & Sequencing of the pediocin operon & CTT GCT CGA TAA TGG TAA & & \\
\hline pedseqB & & CTA TCA GGT AAC TGA AAA & & \\
\hline pedseqC & & CAC GCT TTT CTG ATG CAA & & \\
\hline pedseqD & & TTC TTG ACC CCA TTA GAA & & This study \\
\hline pedseqL & Upstream of operon & AGC AAT TAC AGT CAA CCA TAA CCA T & & \\
\hline pedseqH & & ACA GAG CAG GAA TGT TTG CCA CAA G & 1009 & This study \\
\hline pedseq $M$ & Downstream of operon & ATT GTC TCC GGC ACA ATG TT & & \\
\hline pedseqN & & CAA AGT GGG GAA ACT CGA AA & 1417 & This study \\
\hline pedA2RTF & Real-time PCR & GGC CAA TAT CAT TGG TGG TA & & \\
\hline pedA2RTR & & ATT GAT TAT GCA AGT GGT AGC C & & \\
\hline TqM-pedA & & $\begin{array}{l}\text { FAM-ACT TGT GGC AAA CAT TCC TGC } \\
\text { TCT GTT GA-TAMRA }\end{array}$ & 100 & This study \\
\hline
\end{tabular}

All reactions were done in triplicate and repeated three times.

\section{Results \\ Phenotypic identification of strain UVAI as Pediococcus acidilactici}

A carbohydrate fermentation profile was performed using API $50 \mathrm{CHL}$ strips after $72 \mathrm{~h}$ anaerobic incubation at $37^{\circ} \mathrm{C}$. Using the APILAB+ software and $P$. acidilactici DSM20284T,$P$. acidilactici UL5 (pediocin-producer) and $P$. pentosaceus DSM20336 ${ }^{\mathrm{T}}$ as control strains, UVA1 was identified as Pediococcus acidilactici. Strains UVA1, UL5 and DSM20284 ${ }^{\mathrm{T}}$ differed from each other. Mannose was fermented by UL5 and DSM20284 ${ }^{\mathrm{T}}$ but not by UVA1. Saccharose was only fermented by UL5 and DSM20336 whereas D-trehalose was only fermented by DSM20284 ${ }^{\mathrm{T}}$ and DSM20336 ${ }^{\mathrm{T}}$. Using optical density measurement at $600 \mathrm{~nm}$ after $96 \mathrm{~h}$ incubation, strain UVA1, as well as $P$. acidilactici DSM20284Tand UL5, were shown to grow at $50^{\circ} \mathrm{C}$, whereas $P$. pentosaceus DSM20336 ${ }^{\mathrm{T}}$ didn't.

\section{Genotypic confirmation of the identity of $P$. acidilactici UVAI}

The $16 \mathrm{~S}$ rDNA sequences of strain UVA1 and $P$. acidilactici UL5 were analysed using the software BioEdit [26]. The assembly of sequence fragments produced a 1492 and 1568 bp sequences for strains UVA1 and UL5, respectively. The sequences, compared with 16S rDNA sequences in the GenBank, showed $99 \%$ similarity with the type strain Pediococcus acidilactici DSM20284T. The results of $16 \mathrm{~S}$ rDNA sequencing identified strain UVA1 as a new Pediococcus acidilactici strain. Furthermore, the 16S sequences of strains $P$. acidilactici UVA1 and UL5 were also
99\% similar, showing a close relationship between these two strains.

\section{Biochemical characterization of the antimicrobial compound produced by $P$. acidilactici UVAI}

Heating the cell-free supernatant (CFS) at $121^{\circ} \mathrm{C}$ for 15 min destroyed the inhibitory activity against Listeria ivanovii $\mathrm{HPB} 28$, whereas heat treatments at $100^{\circ} \mathrm{C}$ for 40 and 60 min only yielded a slight reduction of the activity with 80 and $75 \%$ residual activity, respectively. Activity remained unaffected after one month storage at $4^{\circ} \mathrm{C}$ at $\mathrm{pH}$ values from 2 to 8 . At pH 10 and 11, total loss of activity was already observed after 1 week storage and only $60 \%$ of the initial activity was still measurable after 1 month at pH 9. Treatment with proteolytic enzymes such as chymotrypsin, pepsin, protease, proteinase $\mathrm{K}$ or trypsin resulted in a total loss of activity while lysozyme, catalase and other agents tested had no effect.

\section{Determination of the molecular weight}

As shown in Figure 1, SDS-PAGE of the partially purified bacteriocin (concentrated active FPLC-fraction) showed a diffuse band on the Coomassie-stained gel while a clear inhibition halo was visible on the activity-gel for the concentrated FPLC-fraction as well as for the CFS. The relative mobility of the inhibition zone on the gel overlaid with Listeria ivanovii HBP28 was compared to that of the standards stained with Coomassie blue. The apparent molecular weight of the bacteriocin was estimated in the range of 4.5 to $5 \mathrm{kDa}$. The biochemical properties and the molecular weight described above, as well as the fact that this proteinaceous compound is produced by a Pediococcus strain suggest that the anti-Listeria compound is a pediocin-like 
bacteriocin. A genetic approach was used to confirm this assumption.

\section{Genetic characterization of the bacteriocin}

Primers P1 and P2 were used to amplify and sequence a 711-bp fragment (from $91 \mathrm{bp}$ upstream of pedA to $33 \mathrm{bp}$ downstream of the translational start of pedC [GenBank: M83924]) including the ribosome binding site as well as the -35/-10 region. The remaining sequence of the operon (2862 bp, from $13 \mathrm{bp}$ upstream the end of pedB to the end of pedD) was amplified with primers pedopF and pedopR (Table 1) and the generated DNA fragment was sequenced. This resulted in a 3473-bp sequence, comprising the four genes constituting the operon including the upstream region of pedA ( $91 \mathrm{bp}$ ), presumably containing the regulatory elements of the operon. The whole nucleotide sequence showed more than $99.5 \%$ similarity to the published sequences for $P$. acidilactici K1 [GenBank: AY705375], P. acidilactici H [GenBank: U02482], P. acidilactici PAC1.0 [GenBank: M83924], P. pentosaceus [GenBank: AY316525], Lactobacillus plantarum [GenBank: AY316526], P. parvulus [GenBank: AY316524], and Bacillus coagulans [GenBank: AF300457]. Two sequences of 1009 and $1417 \mathrm{bp}$, upstream and downstream of the operon, respectively, were also PCR-amplified and sequenced. The resulting 5368-bp sequence was $99 \%$ identical to the pediocin-encoding plasmid PSRQ11 described for $P$. acidilactici PA-1 [27].

\section{The antimicrobial activity is linked to the presence of the} plasmid and the expression of pedA

Agarose gel electrophoresis of plasmid DNA preparation from strain UVA1 showed three bands: two extrachromosomal DNA elements at $9.5 \mathrm{~kb}$ and at $>10 \mathrm{~kb}$ and one corresponding to chromosomal DNA, respectively (Figure 2(a)). For strain bac-, a non-inhibitory derivative of $P$. acidilactici UVA1 obtained after plasmid curing, in contrast, only chromosomal DNA was visible. Plasmid DNA prepared from the control pediocin producing strain UL5 exhibited the same bands as detected for UVA1, in addition to two larger extrachromosomal DNA elements. Southern hybridization with the pedA-probe (Figure 2(b)) yielded positive signals for the $9.5-\mathrm{kb}$ and the $>10-\mathrm{kb}$ extrachromosomal elements present in UL5 and UVA1, but no hybridization occurred for bac-, confirming the presence of the pedA-gene on the 9.5-kb plasmid, the band at $>10 \mathrm{~kb}$ probably being the relaxed circular form of the same plasmid. The presence of the pedA-gene on the plas-

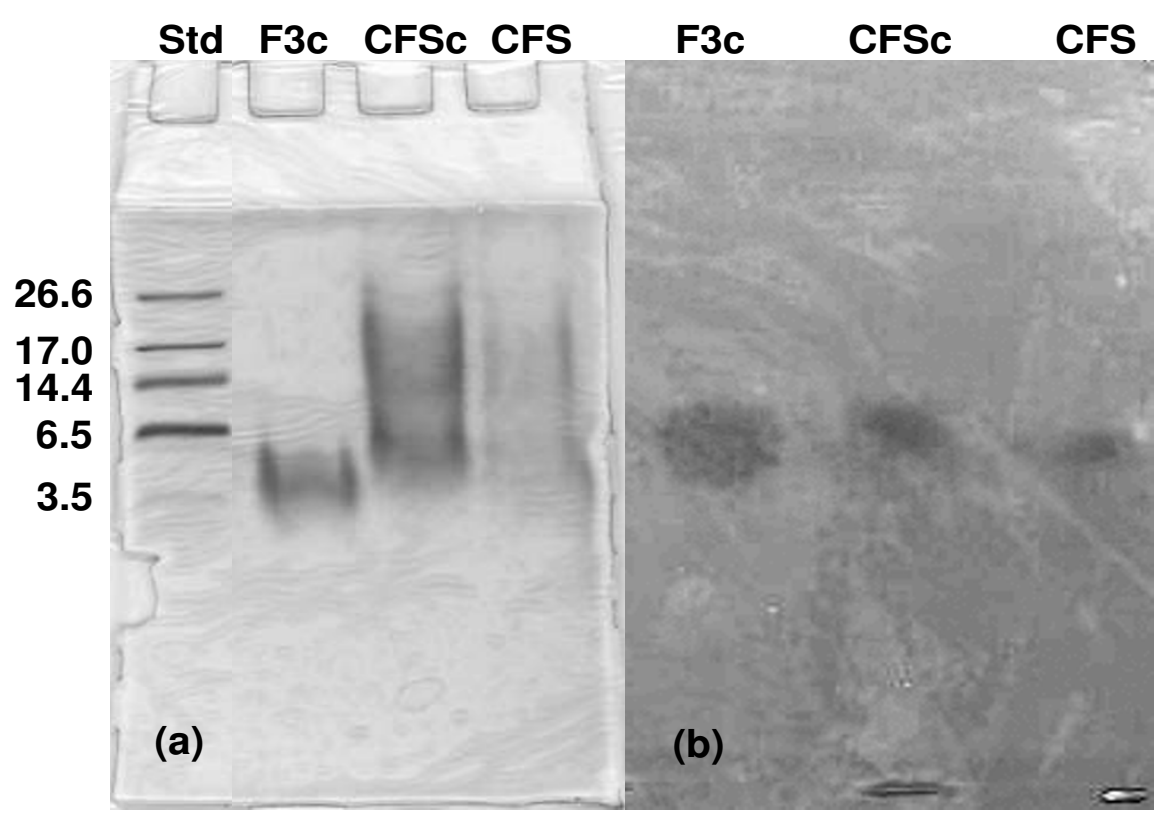

\section{Figure I}

Molecular weight determination of the bacteriocin produced by strain UVA I. (a) Coomassie stained SDS-PAGE gel. (b) SDS gel overlaid with the indicator strain Listeria ivanovii HPB28. Std: polypeptide molecular weight standard in kDa, F3c: active FPLC-fraction I0-fold concentrated. CFSc: cell-free supernatant of a UVAI culture, I0-fold concentrated. CFS: cell-free supernatant not concentrated. 
mid was confirmed by an agar-well diffusion assay, where the supernatant of a culture of the bac- strain failed to exhibit inhibition of the indicator strain Listeria ivanovii HPB28 (Figure 2(c) and 2(d)). Furthermore, the pedAtranscript was detected by reverse-transcription-PCR on cDNA from $P$. acidilactici UVA1 (Figure 3, lanes 7-9) but not from the cured derivative bac- (Figure 3, lanes 1-3), providing the ultimate link between presence of the plasmid-localized genetic determinant and expression of the bacteriocin. The presence of a slight band at $100 \mathrm{bp}$ for the non-plasmid containing strains (Figure 3, lanes 1-4) could not be explained, but the very weak intensity compared to lanes 7 to 9 does not represent a positive signal. A second PCR, performed with primers P1 and P2 (Table 1), which encompass the regulatory region upstream of the transcriptional start, resulted in no amplification in samples using cDNA as template, allowing us to exclude genomic DNA contamination in the RNA preparation of UVA1, UL5 and P. pentosaceus DSM 20336 ${ }^{\mathrm{T}}$ (data not shown).

\section{Distribution of pedA-containing strains in human faecal samples}

The designed primers and probe allowed specific amplification of a 100-bp fragment located within the pedA-gene. As determined with spiked samples, the reaction was linear for concentrations ranging from $10^{9}$ to $10^{5}$ of $P$. acidi- lactici UVA1 cells per g of spiked faeces, corresponding to Ct values comprised between 22 and 35 (Figure 4(a)). A Ct value of 35 was thus fixed as the upper limit for detection. Samples with a higher value were considered not to contain any pedA-gene. With this assay, the pediocin gene was detected in DNA isolated from 11 out of 13 children faecal samples tested, but in none of the 4 adult samples (Figure 4(b)).

\section{Discussion}

Data obtained from phenotypic characterization indicated that strain UVA1 is a Pediococcus acidilactici. The carbohydrate fermentation profile matched that described for $P$. acidilactici in the APILAB+ database and in the literature [8]. Furthermore, among Pediococcus species, only $P$. acidilactici is able to grow at $50^{\circ} \mathrm{C}$ [8]. It is currently accepted that the phenotypic characterization of a strain is not enough to discriminate species or even strains and a polyphasic approach for species identification is recommended [28]. The genotypic characterization using $16 \mathrm{~S}$ rDNA sequence analysis confirmed the data from the phenotypic characterization, with strain UVA1 showing more than $99 \%$ similarity to the $16 \mathrm{~S}$ sequences of other $P$. acidilactici strains. Mora et al. 2000 [29] used restriction fragment length polymorphism (RFLP) of housekeeping genes and 16S rDNA sequence analysis to distinguish between pediocin- and non-pediocin-producing $P$. acidi-

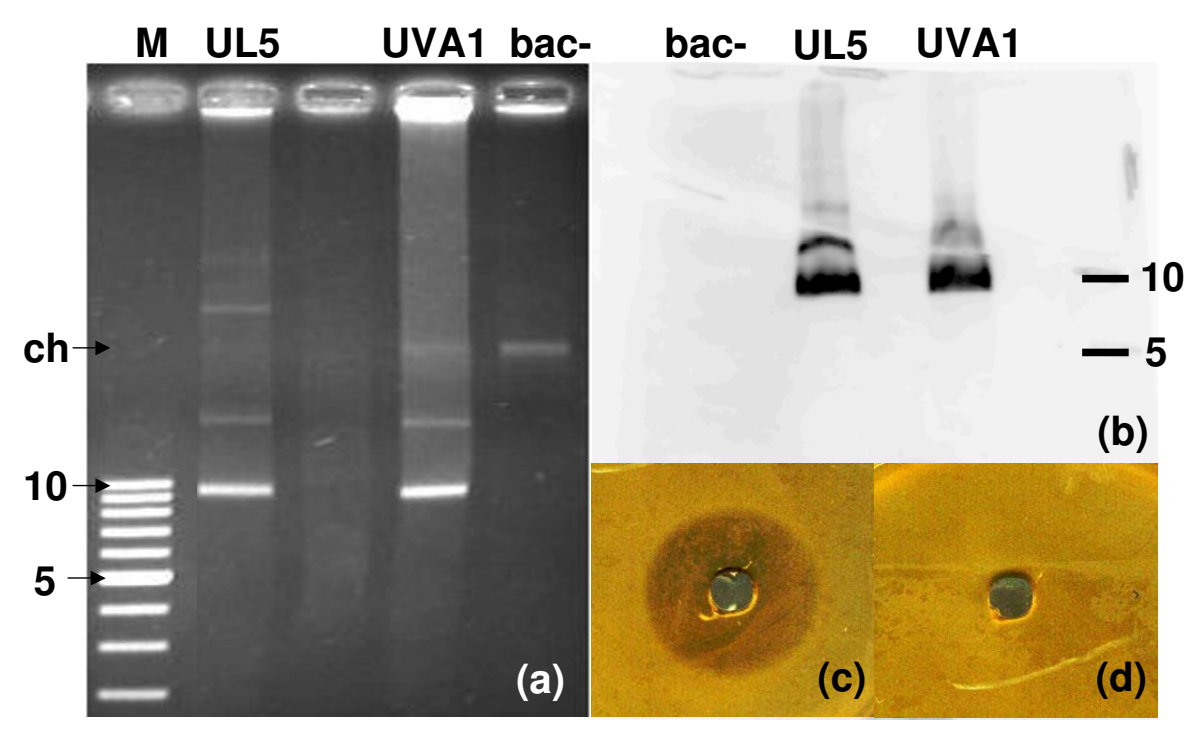

Figure 2

Localization of the pedA gene on the plasmid by curing and Southern blotting. (a) Agarose gel electrophoresis of plasmid DNA. UVAI: P. acidilactici UVAI. UL5: P. acidilactici UL5. bac-: cured derivative of UVAI. M. Supercoiled DNA ladder in kb. ch: chromosomal DNA band. (b) Southern blot DNA hybridization of the DIG labeled pedA-probe with plasmidic DNA from P. acidilactici bac-, UVAI and UL5. (c) and (d) Agar-well diffusion assay with CFS of cultures of P. acidilactici UVAI (c) and its cured derivative $P$. acidilactici bac- (d). 


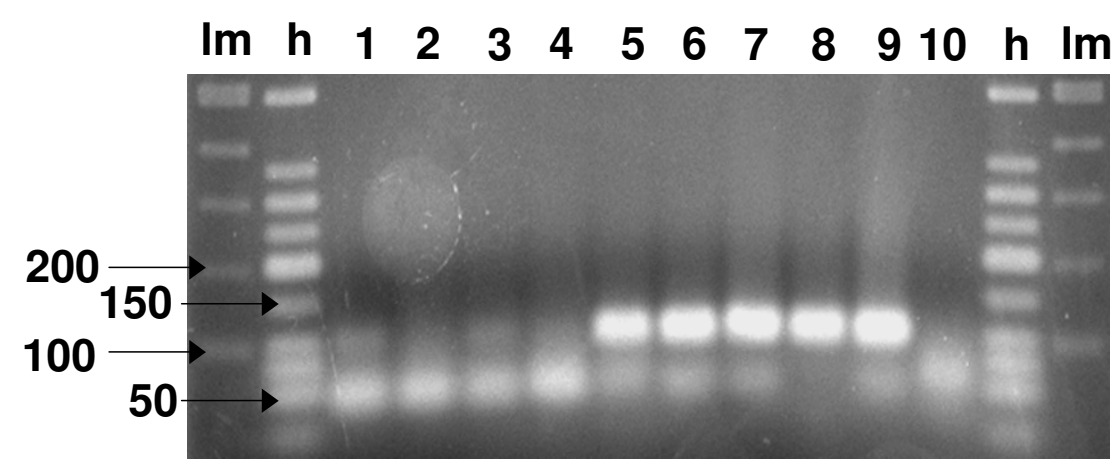

\section{Figure 3}

Transcription analysis of pedA. pedA-reverse transcription-PCR on cDNA from $P$. acidilactici bac- $(\mathrm{I}, 2,3)$ or UVAI $(7,8,9)$ after I h 30, 2 h 30 and 3 h 30 of growth, respectively, and from P. acidilactici DSM 20284'(4) or UL5 (6) and P. pentosaceus DSM $20336^{\top}$ (5) after 2 h 30 of growth. 10: water instead of DNA. Im: low molecular weight DNA ladder (in bp). h: Tridye I00-bp DNA ladder (in bp). Expected product size: 100 bp.

lactici strains and showed that the pediocin-producing strains represented a homogenous subpopulation. This is supported by our observation that strains UVA1 and UL5, two pediocin-producing Pediococcus acidilactici, are very closely related in regard to $16 \mathrm{~S}$ sequence similarity.

P. acidilactici UVA1 inhibited L. ivanovii HPB28 by production of a proteinaceous compound, as demonstrated by the total loss of activity after proteolytic treatments. This compound had a molecular weight of approximately $4.5 \mathrm{kDa}$, similar to pediocin PA-1. This was confirmed by the detection in strain UVA1 of a plasmid of approximately $9.5 \mathrm{~kb}$, on which we could localize the pedA-gene. We also found that the pediocin operon, which consists of the pediocin structural gene ( $p e d A$ ), the specific immunity gene $(p e d B)$, and genes required for processing, maturation and secretion of the bacteriocin (pedC and $D$ ), showed 99 to $100 \%$ similarity to the published sequences for the pediocin PA-1/AcH operon [24,27]. In all pediocin-producing strains isolated so far, the genetic determinants are plasmid-encoded [5]. The comparison of genetic determinants of many pediocin-like producer strains [30] showed that all pediocin genes were carried by plasmids, but the surrounding sequences on the plasmids can differ from one strain to the other. Sequencing data for the regions upstream the regulatory region and downstream the transcription terminator of the pediocin operon in UVA1 suggested that the plasmid harboured by P. acicilactici UVA1 is probably identical to PSRQ11, a $9.4 \mathrm{~kb}$ plasmid from P. acidilactici PA-1 [24].

Transcription analysis by reverse-transcription PCR using primers specific for the mRNA transcript of a particular protein is a straightforward method to establish the link between the presence of the genetic determinant and the observed protein activity. With this direct method, we could show that the pedA-transcript was synthesized in exponentially growing cells of UVA1 but not in the cured,

(a)

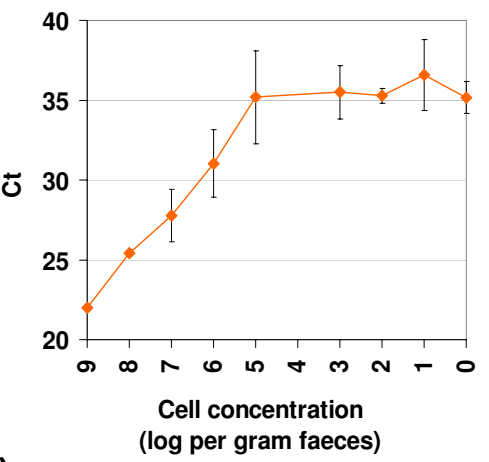

(b)

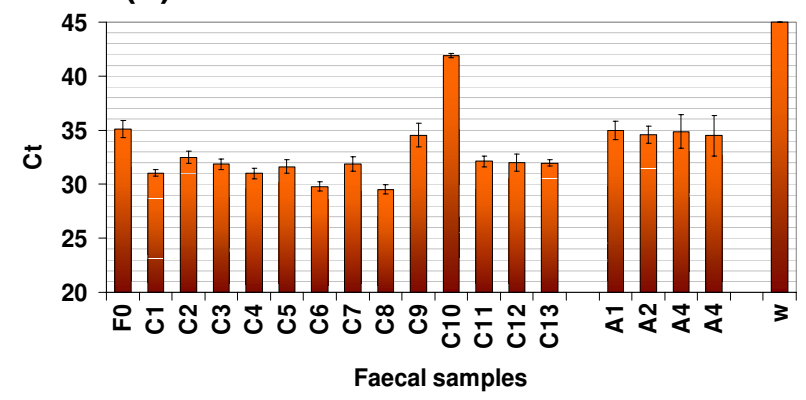

\section{Figure 4}

Real-time PCR on faecal DNA samples. (a) Ct values of spiked samples plotted against spiked cell concentration in faecal DNA sample. (b) Ct values obtained for children $(\mathrm{Cl}$ $\mathrm{CI}$ ) and adult (AI-A4) faecal samples. F0: faecal sample free of DNA. w: water instead of DNA. Values represented are means and standard deviations for 3 repetitions. 
non-active derivative, bac-, and that the inhibitory activity of UVA1 was due to pediocin production. It is also interesting to notice that in P. pentosaceus DSM 20336 ${ }^{\mathrm{T}}$, the pedA-gene and the mRNA transcript were detected, but no inhibitory activity was observed against L. ivanovii HPB28 and the PCR with primers pedopF and pedopR did not yield any product (data not shown). Diep et al. [31] reported similar observations in $P$. pentosaceus ATCC 25745, where a truncated pen locus lead to low expression of antimicrobial activity.

Pediococci are commonly associated with various plants and their products or meat $[8,32]$.) There are only few reports on pediococci detected in human faeces or gastrointestinal tract $[12,33,34]$, and only Millette et al. [12], reported the presence of an antibacterial compound of proteinaceous nature, although not identified yet. Strain UVA1 is, to our knowledge, the first pediocin-producing Pediococcus to be isolated from human faecal material, which characteristic could be particularly interesting for the food industry for biopreservation as well as for possible probiotic effect. In this work, we showed, with a new real-time PCR assay, that strains containing the pedA-gene are relatively widespread in baby faecal material, but were not found in the 4 adult samples tested. Therefore, human faecal material could be a good source for isolating new pediocin-producing strains.

\section{Conclusion}

Strain UVA1, isolated from new born faeces, was clearly identified as a Pediococcus acidilactici using a polyphasic approach. Data for the molecular size, sensitivity to protease and sequence of the plasmid-borne genetic determinant indicated that the antibacterial compound produced by UVA1 is pediocin PA-1/AcH. To our knowledge, Pediococcus acidilactici UVA1 is the first pediocin-producing Pediococcus strain isolated from human faeces. Real-time PCR was an efficient method for detection of specific genes in faecal samples harbouring a complex microbiota. We showed a large distribution of pedA-containing strains in baby faecal samples.

\section{Authors' contributions}

SM participated in the study design and carried out the identification of the bacteriocin and the genetic study. UVA contributed to the study design, isolated and identified the strain UVA1 and participated in the writing of the manuscript. ES contributed to the characterisation of the strain. RM performed the real-time PCR screening of faecal samples. TC participated in the identification of the genetic determinant. LM and CL provided guidance during all parts of the work. All authors read and approved the final manuscript.

informatics Methods and Protocols: Methods in Molecular Biology Edited

\section{Acknowledgements}

This work was supported by the Swiss National Foundation (Project no. 3100A0-102256).

\section{References}

I. Drider D, Fimland G, Hechard Y, McMullen LM, Prévost H: The continuing story of class Ila bacteriocins. Microbiol Mol Biol Rev 2006, 70(2):564-582.

2. Devlieghere F, Vermeiren L, Debevere J: New preservation technologies: Possibilities and limitations. Int Dairy J 2004, I 4(4):273-285.

3. Cotter PD, Hill C, Ross RP: Bacteriocins: developing innate immunity for food. Nat Rev Microbiol 2005, 3( 1 0):777-788.

4. Eijsink VGH, Axelsson L, Diep DB, Havarstein LS, Holo H, Nes IF: Production of class II bacteriocins by lactic acid bacteria; an example of biological warfare and communication. Antonie Van Leeuwenhoek 2002, 8 I (I - 4):639-654.

5. Rodriguez JM, Martinez MI, Kok J: Pediocin PA-I, a wide-spectrum bacteriocin from lactic acid bacteria. Crit Rev Food Sci Nutr 2002, 42(2):91-121.

6. Henderson JT, Chopko AL, van Wassenaar PD: Purification and primary structure of pediocin PA-I produced by Pediococcus acidilactici PAC-I.0. Arch Biochem Biophys I992, 295(I):5-I2.

7. Nieto Lozano JC, Meyer JN, Sletten K, Pelaz C, Nes IF: Purification and amino acid sequence of a bacteriocin produced by Pediococcus acidilactici. J Gen Microbiol 1992, I38(9): 1985-1990.

8. Carr FJ, Chill D, Maida N: The lactic acid bacteria: a literature survey. Crit Rev Microbiol 2002, 28(4):28I-370.

9. Juven BJ, Meinersmann RJ, Stern NJ: Antagonistic effects of lactobacilli and pediococci to control intestinal colonization by human entero-pathogens in live poultry. J Appl Bacteriol I99I, 70:95-103.

10. Kurzak P, Ehrmann MA, Vogel RF: Diversity of lactic acid bacteria associated with ducks. Syst Appl Microbiol 1998, 2 I :588-592.

II. Hudson JA, Cai Y, Corner RJ, Morvan B, Joblin KN: Identification and enumeration of oleic acid and linoleic acid hydrating bacteria in the rumen of sheep and cows. J Appl Microbiol 2000, 88(2):286-292.

12. Millette M, Dupont C, Archambault D, Lacroix M: Partial characterization of bacteriocins produced by human Lactococcus lactis and Pediococccus acidilactici isolates. J Appl Microbiol 2007, I 02(I):274-282.

13. Stewart JA, Chadwick VS, Murray A: Carriage, quantification, and predominance of methanogens and sulfate-reducing bacteria in faecal samples. Lett Appl Microbiol 2006, 43(I):58-63.

14. Maruo T, Sakamoto M, Toda T, Benno Y: Monitoring the cell number of Lactococcus lactis subsp. cremoris $F C$ in human feces by real-time PCR with strain-specific primers designed using the RAPD technique. Int J Food Microbiol 2006, I I 0(I):69-76.

15. Houde A, Leblanc D, Poitras E, Ward P, Brassard J, Simard C, Trottier YL: Comparative evaluation of RT-PCR, nucleic acid sequence-based amplification (NASBA) and real-time RTPCR for detection of noroviruses in faecal material. J Virol Methods 2006, I35(2): 163-172.

16. Touré R, Kheadr E, Lacroix C, Moroni O, Fliss I: Production of antibacterial substances by bifidobacterial isolates from infant stool active against Listeria monocytogenes. J Appl Microbiol 2003, 95(5): I058-1069.

17. Daba H, Lacroix C, Huang J, Simard RE, Lemieux L: Simple method of purification and sequencing of a bacteriocin produced by Pediococcus acidilactici UL5. J Appl Bacteriol 1994, 77(6):682-688.

18. Halami PM, Ramesh A, Chandrashekar A: Megaplasmid encoding novel sugar utilizing phenotypes, pediocin production and immunity in Pediococcus acidilactici C20. Food Microbiol 2000, I 7(5):475-483.

19. de Man JD, Rogosa M, Sharpe ME: A medium for the cultivation of Lactobacilli. J Appl Bacteriol 1960, 23:130-I35.

20. Schägger $H$, von Jagow $G$ : Tricine-sodium dodecyl sulfate-polyacrylamide gel electrophoresis for the separation of proteins in the range from I to $100 \mathrm{kDa}$. Anal Biochem 1987, I66(2):368.

21. Rozen S, Skaletsky HJ: Primer3 on the WWW for general users and for biologist programmers. In Krawetz S, Misener S (eds) Bioby: Press H. Totowa ; 2000:365-386. 
22. Schürch C: Development of a novel DNA transformation system for bifidobacteria. In Dept of Agricultural and Food Sciences Zurich, Swiss Federal Institute of Technology; 2002.

23. Rodriguez JM, Cintas LM, Casaus P, Martinez MI, Suarez A, Hernandez PE: Detection of pediocin PA-I-producing pediococci by rapid molecular biology techniques. Food Microbiol 1997, |4(4):363-37I.

24. Marugg JD, Gonzalez CF, Kunka BS, Ledeboer AM, Pucci MJ, Toonen MY, Walker SA, Zoetmulder LC, Vandenbergh PA: Cloning, expression, and nucleotide sequence of genes involved in production of pediocin PA-I, a bacteriocin from Pediococcus acidilactici PACI.0. Appl Environ Microbiol 1992, 58(8):2360-2367.

25. Anderson DG, McKay LL: Simple and rapid method for isolating large plasmid DNA from lactic streptococci. Appl Environ Microbiol 1983, 46:549-552.

26. BioEdit, biological sequence alignment editor for Win 95/98/ NT/2K/XP.

27. Motlagh A, Bukhtiyarova M, Ray B: Complete nucleotide sequence of pSMB 74, a plasmid encoding the production of pediocin AcH in Pediococcus acidilactici. Lett Appl Microbiol 1994, 18(6):305-312.

28. Vandamme P, Pot B, Gillis M, de Vos P, Kersters K, Swings J: Polyphasic taxonomy, a consensus approach to bacterial systematics. Microbiol Rev 1996, 60:407-438.

29. Mora D, Fortina MG, Parini C, Daffonchio D, Manachini PL: Genomic subpopulations within the species Pediococcus acidilactici detected by multilocus typing analysis: relationships between pediocin AcH/PA-I producing and non-producing strains. Microbiology 2000, I46(8):2027-2038.

30. Miller KW, Ray P, Steinmetz T, Hanekamp T, Ray B: Gene organization and sequences of pediocin AcH/PA-I production operons in Pediococcus and Lactobacillus plasmids. Lett Appl Microbiol 2005, 40:I-56.

31. Diep DB, Godager L, Brede D, Nes IF: Data mining and characterization of a novel pediocin-like bacteriocin system from the genome of Pediococcus pentosaceus ATCC 25745. Microbiology 2006, I 52(6): 1649-1659.

32. Simpson PJ, Stanton C, Fitzgerald GF, Ross RP: Genomic diversity within the genus Pediococcus as revealed by randomly amplified polymorphic DNA PCR and Pulsed-Field Gel Electrophoresis. Appl Environ Microbiol 2002, 68(2):765-77I.

33. Barros RR, Carvalho MDGS, Peralta JM, Facklam RR, Teixeira LM: Phenotypic and genotypic characterization of Pediococcus strains isolated from human clinical sources. J Clin Microbiol 200I, 39(4): |24|-|246.

34. Walter J, Hertel C, Tannock GW, Lis CM, Munro K, Hammes WP: Detection of Lactobacillus, Pediococcus, Leuconostoc, and Weissella species in human feces by using group-specific PCR primers and denaturing gradient gel electrophoresis. Appl Environ Microbiol 200I, 67(6):2578-2585.

35. Goldenberger D, Perschil I, Ritzler M, Altwegg M: A simple "universal" DNA extraction procedure using SDS and proteinase $\mathbf{K}$ is compatible with direct PCR amplification. PCR Methods Appl 1995, 4:368-370.

36. Greisen K, Loeffelholz M, Purohit A, Leong D: PCR primers and probes for the I6S rDNA gene of most species of pathogenic bacteria, including bacteria found in cerebrospinal fluid. J Clin Microbiol 1994, 32:335-351.
Publish with Bio Med Central and every scientist can read your work free of charge

"BioMed Central will be the most significant development for disseminating the results of biomedical research in our lifetime. "

Sir Paul Nurse, Cancer Research UK

Your research papers will be:

- available free of charge to the entire biomedical community

- peer reviewed and published immediately upon acceptance

- cited in PubMed and archived on PubMed Central

- yours - you keep the copyright
BioMedcentral 